\title{
Litterär flerspråkighet i fokus
}

\section{Julia Tidigs: Att skriva sig över språkgränserna. Flerspråkighet i Jac. Ahrenbergs och Elmer Diktonius prosa. Åbo: Åbo Akademis förlag, 20 I 4 . 348 s.}

Julia Tidigs har gett sin doktorsavhandling i litteraturvetenskap en spännande titel som omedelbart väcker intresse: Att skriva sig över språkgränserna. Men undertiteln Flerspråkighet i Jac. Ahrenbergs och Elmer Diktonius prosa väcker också genast ett par frågor: Varför sammanförs Jac. Ahrenberg, en författare som få torde känna till i dag, med Elmer Diktonius? Varför undersöks fenomenet litterär flerspråkighet i just dessa två författares prosatexter inom ramen för samma avhandlingsprojekt?

Som skönlitterär författare har Jac. Ahrenberg (1847-1914) fallit i glömska, men Tidigs framhåller att han under sin livstid var mycket läst, också på finskt håll och i Sverige. Ahrenberg var född i det flerspråkiga Viborg. Han var verksam som arkitekt och samtidigt mycket produktiv som författare. Han skrev berättelser, noveller och romaner, de flesta med motiv från östra Finland, samt ett stort antal kåserier och tidningsartiklar. Största delen av hans skönlitterära texter kom ut på 1880- och | 890-talen, under en tid då en svensk nationalitetsrörelse småningom växte fram men då det ännu inte fanns någon enhetlig eller kodifierad norm för svenskan i Finland. Ahrenbergs skönlitterära prosaböcker fick emellertid redan från början också en del negativ kritik och det var främst på grund av språket. Flera recensenter påtalade hans bristfälliga och slarviga svenska. När hans Samlade berättelser skulle ges ut i början av 1920-talet blev texterna föremål för omfattande språkliga och även stilistiska revideringar.

Elmer Diktonius (1896-196I) debuterade 192I med en samling aforismer och dikter. Vid den tidpunkten hade en norm för finlandssvenskan etablerats $\mathrm{i}$ och med Hugo Bergroths verk Finlandssvenska. Handledning till undvikande av provinsialismer i tal och skrift (1917). Termen finlandssvensk hade slagit igenom (som Tidigs påpekar kan Diktonius kallas finlandssvensk, men inte Ahrenberg) och modernismen hade trätt fram med Edith Södergran och Hagar Olsson.

Eftersom Ahrenberg debuterade i slutet av 1870-talet och Diktonius sista prosaverk kom ut 1943 spänner Tidigs undersökning över en lång tidsperiod, från 1870-tal till 1940-tal. Mellan de texter som undersöks, Ahrenbergs prosa som av Tidigs beskrivs som realistisk "med en dragning åt det romantiska", och Diktonius som hon uttrycker det "vanvördiga expressionism", finns det uppenbara och radikala skillnader (s. 27). Ett syfte med att undersöka två så olika författarskap som har så skilda förutsättningar är, framhåller hon, "att visa upp något av den textuella flerspråkighetens väldiga mångfald och litterära potential" (s.l7). Här får vi alltså en förklaring till Tidigs val av just dessa två författare. 
Men hon betonar att de två författarskapen inte har valts som "polära exempel" och att flerspråkigheten utgör en "omistlig del" av bådas författarskap (s. 27, s. 17).

Vad avser Tidigs då med litterär flerspråkighet, textuell flerspråkighet och litterär språkblandning, termer som används synonymt i avhandlingen? Det kan vara inskott i den svenska huvudtexten av ord, uttryck och fraser på andra språk - i materialet förekommer till exempel franska, finska, ryska, tyska, engelska och jiddisch - det kan vara hybridord och icke-idiomatiska uttryck och det kan vara ortografiska, syntaktiska och semantiska avvikelser. Också flerspråkighet som ett motiv i texterna betraktas av Tidigs som en manifestation av litterär flerspråkighet. En viktig aspekt i avhandlingen är vidare diskussionen om flerspråkighet i relation till begrepp som modersmål, språktillhörighet, språkgränsers naturlighet, folk och nation. Här utmanas många invanda föreställningar och gängse uppfattningar.

När Tidigs utforskar fenomenet litterär flerspråkighet i sitt material är det språkbruket, det konkreta bruket av olika språk som utgör utgångspunkten för analysen och diskussionen. Den fråga som genomsyrar undersökningen är: Vad gör, vad åstadkommer texten genom att vara flerspråkig, vilka är effekterna av att språk blandas? Det innebär att tillvägagångssättet är induktivt och att fenomenet inte kan analyseras utifrån någon på förhand uppgjord formell kategorisering; de flerspråkiga elementen måste kontextualiseras, relateras till texten som helhet. En intressant fråga här är vad en flerspråkig text kan åstadkomma som en enspråkig text inte kan. Förekomsten av främmande element i den svenska huvudtexten aktualiserar också frågor om integration och det som i avhandlingen kallas glossering. De främmande elementen kan vara grammatiskt integrerade $\mathrm{i}$ texten eller typografiskt markerade; de kan också stå som självständiga, separata enheter i den svenska texten. Med den närbesläktade termen glossering avses om de främmande inslagen översätts, parafraseras eller förklaras på något sätt eller om de helt enkelt lämnas oförklarade. Alla de här dragen inverkar på flerspråkighetens effekter.

Tidigs påpekar att tidigare forskning om litterär flerspråkighet (åtminstone i Finland) i första hand har varit en angelägenhet för språkvetare. Språkvetenskapliga undersökningar har emellertid tenderat att betrakta litterär flerspråkighet som "språkligt exempelmaterial” där intresset fokuserats på formella grammatiska kategorier och på avvikelser från språknormen. Språkvetare använder vanligen termerna kod och kodväxling när de studerar förekomsten av andra språk i en text - eller $i$ ett samtal - och det är termer som Tidigs vill undvika. Man kan notera att hon skrev sin magisteravhandling (tryckt 2003) om Ahrenbergs roman Familjen på Haapakoski (1893) där inslag på bland annat franska förekommer, och att termen kodväxling ingår $\mathrm{i}$ den avhandlingens titel. Hon menar nu att en syn på språk som kod är problematisk att omfatta (i synnerhet när det gäller Diktonius); det vittnar om ett enspråksnormativt tänkande med en "ren" kod som utgångspunkt (s. 68). Tidigs verkar 
på det hela taget utifrån sitt litteraturvetenskapliga perspektiv förhålla sig tämligen kritisk till språkvetenskapliga undersökningar av litterär flerspråkighet. Men ämnet befinner sig i gränslandet mellan språkvetenskap och litteraturvetenskap, och det är svårt att se att litteraturvetare skulle klara sig utan någon form av språklig begreppsapparat (vilket Tidigs inte heller gör). Personligen hoppas jag att gränsen mellan de två disciplinerna ska vara öppen och att litteraturvetare och språkvetare låter sig inspireras av varandra.

En vanlig uppfattning om litterär flerspråkighet är att den är ett redskap för språklig realism, autenticitet och representativitet. Tidigs tar upp den här aspekten i många sammanhang $\mathrm{i}$ avhandlingen. Hennes ståndpunkt är klar: flerspråkigheten kan måhända sägas vara realistisk men autentisk är den inte - även om den kan resultera i ett "sken av autenticitet". Enligt min mening kunde det vara värt att reflektera lite mer över detta: Vad är det som gör att den textuella flerspråkigheten av (en del) kritiker och läsare inte sällan karakteriseras som "äkta" - eller alternativt som icke trovärdig?

För avhandlingen har Tidigs utnyttjat ett rikhaltigt kompletterande material bestående av bland annat brev, recensioner och tidningsartiklar samt givetvis tidigare forskning. Också internationella utblickar över relevant litteratur på området ges. Det är inte möjligt att här gå in på själva undersökningen och dess resultat och slutsatser; ett par kommentarer bara. När det gäller Ahrenbergs författarskap är det tydligt att Tidigs är ute efter ett slags äreräddning (s. 2II). Utifrån hennes framställning framstår hans prosaverk som intressanta ur många synvinklar; problemet är bara att man borde ha tillgång till originalutgåvorna. Kapitlet om Diktonius textuella flerspråkighet kastar nytt ljus över hans prosadiktning som förvånande nog inte hittills varit utforskad i någon större utsträckning. Jag vill här som ett exempel lyfta fram den lilla berättelsen "Josef och Sussan" (ingår i andra samlingen av Medborgare, 1940) som handlar om en kontorsflicka från Sibbo och en judisk klädeshandlare. Läs berättelsen och läs sedan Tidigs analys och kommentarer!

Den digra avhandlingen är spänstigt skriven. Greppet är genomgående resonerande, ifrågasättande, utmanande och ställningstagande. Tidigs går $\mathrm{i}$ dialog med tidigare forskare och också läsaren dras med $\mathrm{i}$ denna dialog. Det är spännande att följa hennes beskrivning av hur Ahrenberg och Diktonius vid olika tidpunkter och på olika sätt skriver sig över språkgränserna.

\section{Författare}

Anne-Marie Londen, professor em., nordiska språk, Helsingfors universitet (anne-marie.londen[at]helsinki.fi) 